\section{NuMex LotaLutein, a Lutein-rich Serrano Pepper}

\author{
Ivette Guzman, Danise Coon, Krystal Vargas, and Paul W. Bosland \\ Department of Plant and Environmental Sciences, New Mexico State \\ University, Las Cruces, NM 88003
}

Additional index words. Capsicum annuum, carotenoids, high-performance liquid chromatography, human health, macular degeneration, open-pollinated

Lutein is a carotenoid with antioxidant and anti-inflammatory properties important for reducing the risks of several chronic diseases (Buscemi et al., 2018). Biofortification is the process by which the nutritional quality of food crops, like lutein, is improved through plant breeding, genetic medication, and other agronomic practices. Biofortification may be a way to overcome lutein deficiency when supplementation and conventional fortification activities may be difficult to implement and/or limited. The New Mexico State University Chile Pepper Breeding Program has announced the release of 'NuMex LotaLutein', a biofortified, luteinrich Capsicum annuum serrano cultivar.

Increasing the amount of lutein, a carotenoid, in chile peppers is important because it can replace synthetic yellow colorants and is considered a nutraceutical ingredient in functional foods. A large body of evidence has shown that lutein has several beneficial effects, especially on eye health (Buscemi et al., 2018). For adults older than 65 years living in industrialized countries, age-related macular degeneration is the leading cause of blindness. Lutein is known to improve or even prevent age-related macular disease, which is the leading cause of blindness and vision impairment. Other carotenoids that are beneficial to eye health are provitamin A carotenoids such as $\beta$-carotene; however, the body must convert $\beta$-carotene to retinol to provide eye health benefits (Johnson, 2002). In contrast, lutein is more bioavailable than $\beta$-carotene and is active without further

Received for publication 20 Feb. 2020. Accepted for publication 8 Oct. 2020.

Published online 9 November 2020.

A contribution of the New Mexico Agricultural Experiment Station, New Mexico State University, Las Cruces, NM 88003.

We thank the Chile Pepper Institute staff for their technical assistance.

Undergraduate student salaries and research were supported by the state and federal Hatch funds appropriated to New Mexico Agricultural Experiment Station and New Mexico State University's Maximizing Access to Research Careers program funded by the National Institutes of Health.

I.G. is the corresponding author. E-mail: ivguzman@ nmsu.edu.

This is an open access article distributed under the CC BY-NC-ND license (https://creativecommons. org/licenses/by-nc-nd/4.0/). modification by the human body (Johnson, 2002). Sources of lutein are green leafy vegetables, yellow fruits and vegetables, and egg yolks (Johnson, 2002). Furthermore, many studies have reported that lutein may have positive effects on different clinical conditions, thus ameliorating cognitive function, decreasing the risk of cancer, and improving measures of cardiovascular health (Steiner et al., 2018). Lutein carotenoids cannot be synthesized de novo by humans and must be obtained from dietary sources. Given the prevalence of age-related macular degeneration in industrialized countries, such crease in the human population older than 65 years, additional dietary sources of lutein are desired. The widespread popularity of chile pepper in the United States makes it a logical platform to deliver higher amounts of lutein. Chile peppers have a germplasm base with considerable genotypic diversity for lutein, making it possible to successfully select higher levels of lutein.

Serrano peppers are becoming more popular with home gardeners and food manufacturers as an ingredient for salsas and pico de gallo. Most commercial serrano cultivars have fruits that turn from green to red. Personal communications with commercial pepper breeders have stated that in their hot pepper breeding programs, the serrano is the second most important for sales after jalapeño, and that more acreage of serrano peppers is being used for growth in the Yuma, AZ, pepper production area (Kurt Nolte, Yuma Cooperative Extension Agent, personal communication). 'NuMex LotaLutein', which has fruits that turn from green to yellow, not only provides a colorful option in an ever-expanding horticulture market but also offers a lutein-rich carotenoid profile. In addition, 'NuMex LotaLutein' can be used by breeders looking to biofortify other Capsicum species.

\section{Origin}

'NuMex LotaLutein' originated from an $\mathrm{F}_{2}$ segregating population that was derived from selfing a commercial F1 hybrid serrano cultivar that had fruit that changed from green to red at the Leyendecker Plant Science Research Center (LPSRC) $5 \mathrm{~km}$ south of Las Cruces, NM. The field soil was a Glendale loam (pH 7.7). During Summer 2012, the $F_{2}$ as the United States, and the expected in- segregating population produced segregating lines of mature fruit that were red, yellow, and orange. Single-plant selection using phenotypic recurrent selection with pedigree breeding for earliness, desirable fruit shape and size, yield, and ease of destemming was accomplished. A total of seven generations of self-pollination were accomplished using a greenhouse during the winter season. Within the segregating generations, five single-plant selections were made based on the color of ripeness alone. Each selected plant was selfed by stripping fruits and open flowers and then placing an isolation cage over the individual plant to exclude any outcrossing (Bosland, 1993). During each generation of selection, phenotypic traits considered to be important to a serrano pod-type were selected (Bosland and Votava, 2012). In 2013 and 2014, selfed, single-plant selections were planted at the LPSRC, and selections of desired horticultural traits were made and selfed under isolation cages. Two lines from the 2013 and 2015 breeding lines were analyzed using high-performance liquid chromatography (HPLC) to quantify carotenoids. These lines were found to have uniquely high amounts of lutein relative to other carotenoids and no $\beta$-carotene. These lines were analyzed, and New Mexico Chile Accession $15 \mathrm{C} 388-1$ was the line with the highest percentage of lutein; therefore, it became 'NuMex LotaLutein'.

\section{Description and Performance}

The plants were grown using standard growing practices commonly found in southern New Mexico (Bosland and Walker, 2014). 'NuMex LotaLutein' is adapted to the relatively high temperatures and low humidity of New Mexico. The concentrated set of fruit on compact $(36-45 \mathrm{~cm})$ plants makes them ideally suited for commercial production and home gardens. Horticulturally desirable fruits characteristics were recorded for 'NuMex LotaLutein' (Table 1). Each cultivar is green when immature and turns bright yellow (2.5Y 7/12) (Munsell Book of Color, 1980) at maturity (Figs. 1 and 2). Plants and fruit were compared with an open-pollinated cultivar called Serrano (Siegers Seed Co., Holland, MI), with mature red fruits. Replicated trials were performed for 2 years using a randomized complete block design with at least four replications. From each replication, 10 randomly selected plants were used to calculate the means for plant and fruit quality traits. These two cultivars had total weights, 10 pod weights, fruit widths, fruit lengths, and plant heights that were not significantly different. However, the plant widths of the two cultivars were significantly different $(P=0.73)$ (Table 1).

The heat level was determined based on dry weight by a reverse-phase HPLC system with fluorescence detectors (Collins et al., 1995). The mean heat for 'NuMex LotaLutein' was calculated over the course of 2 years and was determined to be 31,498 Scoville Heat Units (Table 1). 
Table 1. Fruit characteristics of 'NuMex LotaLutein' and 'Serrano' over 2 years.

\begin{tabular}{|c|c|c|c|c|c|c|c|}
\hline Cultivar & Total $\mathrm{wt}^{\mathrm{z}}(\mathrm{g})$ & Fruit $w^{\mathrm{y}}(\mathrm{g})$ & Fruit width ${ }^{\mathrm{y}}(\mathrm{cm})$ & Fruit length ${ }^{\mathrm{y}}(\mathrm{cm})$ & Plant ht $(\mathrm{cm})$ & Plant width $(\mathrm{cm})$ & $\mathrm{SHU}^{\mathrm{x}}$ \\
\hline NuMex LotaLutein & 633.2 & 61.5 & 1.5 & 6.0 & 44.3 & $38.1 \mathrm{a}^{\mathrm{w}}$ & 31,498 \\
\hline Serrano & 676.0 & 62.7 & 1.5 & 5.8 & 46.5 & $48.7 \mathrm{~b}$ & 25,132 \\
\hline$P$ value $\left(t\right.$ test $\left.^{\mathrm{w}}\right)$ & 0.84 & 0.39 & 0.73 & 0.33 & 0.38 & 0.01 & 0.07 \\
\hline
\end{tabular}

${ }^{\mathrm{z}}$ Gross weights included all fruit from one plant of four replications per year over 2 years.

${ }^{\mathrm{y}}$ Fruit weight, fruit width, and fruit length were the average of 10 fruits per replication per year over 2 years.

${ }^{\mathrm{x}}$ Scoville Heat Units (SHU) were calculated from the conversion of $1 \mathrm{mg} \cdot \mathrm{kg}^{-1}$ capsaicinoid $=16$ SHU on a dry weight basis. The average SHU was obtained from 10 fruits from each of 4 replications over 2 years.

${ }^{\mathrm{w}}$ Means followed by the different letters are significantly different according to the least significant difference at $P \leq 0.05$.

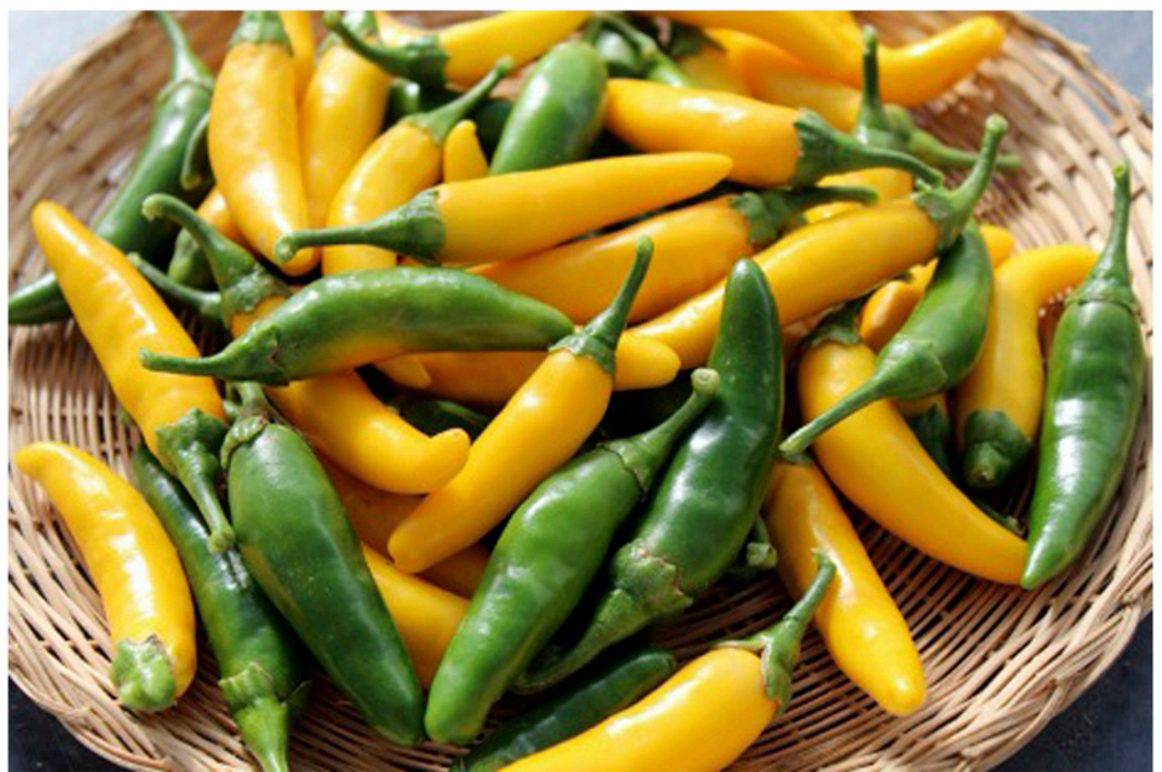

Fig. 1. Mature green and yellow fruits of 'NuMex LotaLutein'.

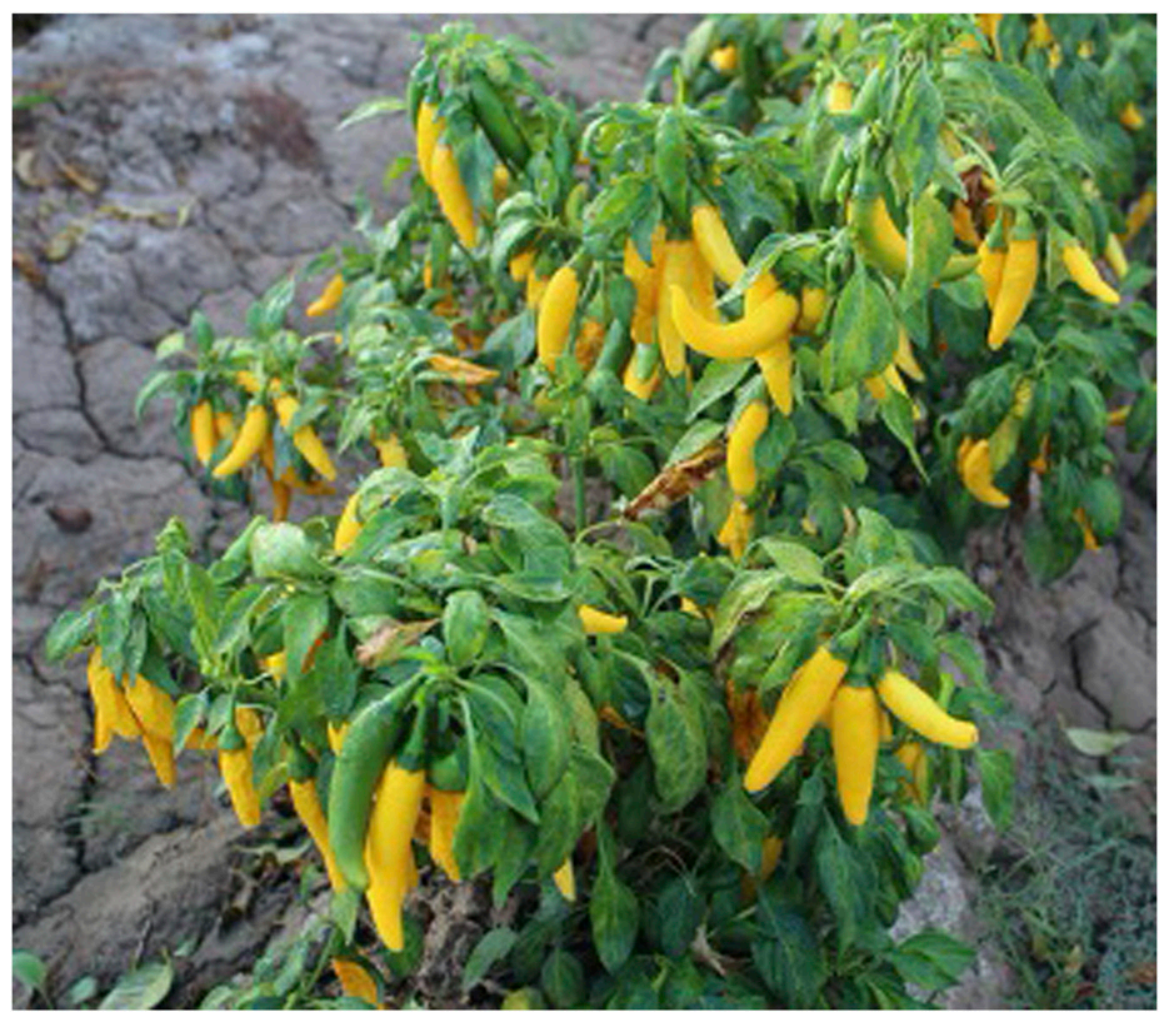

Fig. 2. Whole plant of 'NuMex LotaLutein'.
For lutein extraction and quantitation, pods were harvested at ripeness. Fruit tissue was cut, frozen, and lyophilized to preserve carotenoids. Lyophilized tissue was extracted with hexane, and the extract was saponified using methanolic potassium hydroxide (Guzman et al., 2010). Total lutein and $\beta$-carotene contents were measured by HPLC according to Richins et al. (2014). Lutein and $\beta$-carotene HPLC peaks were identified in 'NuMex LotaLutein' by comparing retention times and light absorbance spectra to those of lutein and $\beta$-carotene standards (Sigma-Aldrich, St. Louis, MO) (Fig. 3). The results indicated that in our solvent system, the retention time of lutein was $10 \mathrm{~min}$, with a maximum light absorbance of $445.9 \mathrm{~nm}$; however, the retention time of $\beta$-carotene was $25.8 \mathrm{~min}$, with a maximum light absorbance of $451 \mathrm{~nm}$. The lutein and $\beta$-carotene peaks in the 'NuMex LotaLutein' HPLC chromatogram were quantified using lutein and $\beta$-carotene standard curves.

Nine unique carotenoids were detected using HPLC; however, lutein was the major carotenoid. 'NuMex LotaLutein' contained $21.9 \mu \mathrm{g} \cdot \mathrm{g}^{-1}$ total lutein and $32.7 \mu \mathrm{g} \cdot \mathrm{g}^{-1}$ total carotenoids, and the selection from 2013 (13C-136) contained $11.35 \mu \mathrm{g} \cdot \mathrm{g}^{-1}$ total lutein and $27.63 \mu \mathrm{g} \cdot \mathrm{g}^{-1}$ total carotenoids. 'NuMex LotaLutein' had more lutein per gram of dried tissue than that previously published for other Capsicum varieties (Table 2), except for the cultivars Morita and Red Paprika, which are, notably, not yellow fruited cultivars (Hervert-Hernandez et al., 2010; Kim et al., 2010). Despite this, the lutein in the cultivars Morita and Red Paprika only comprised $1.8 \%$ and $3.5 \%$ of the total carotenoids, respectively. Lutein comprised $67 \%$ of the total carotenoids in 'NuMex LotaLutein' and only $41 \%$ in the 2013 selection. It is important to not compare the total amounts of lutein in 'NuMex LotaLutein' on a perweight basis with other cultivars because the claim is not that it contains the highest amount of lutein compared with other accessions. The uniqueness of "NuMex LotaLutein' is that more than $60 \%$ of the carotenoids in it are lutein, thereby making it a lutein-rich serrano with high-purity lutein compared with the total carotenoid profiles in the literature. No other published data showed that Capsicum contains a percentage of pure lutein this high relative to total carotenoids. An additional observation worth noting is that 'NuMex LotaLutein' contains only $0.5 \%$ $\beta$-carotene, a commonly found carotenoid in Capsicum. Moreover, there may be variations 

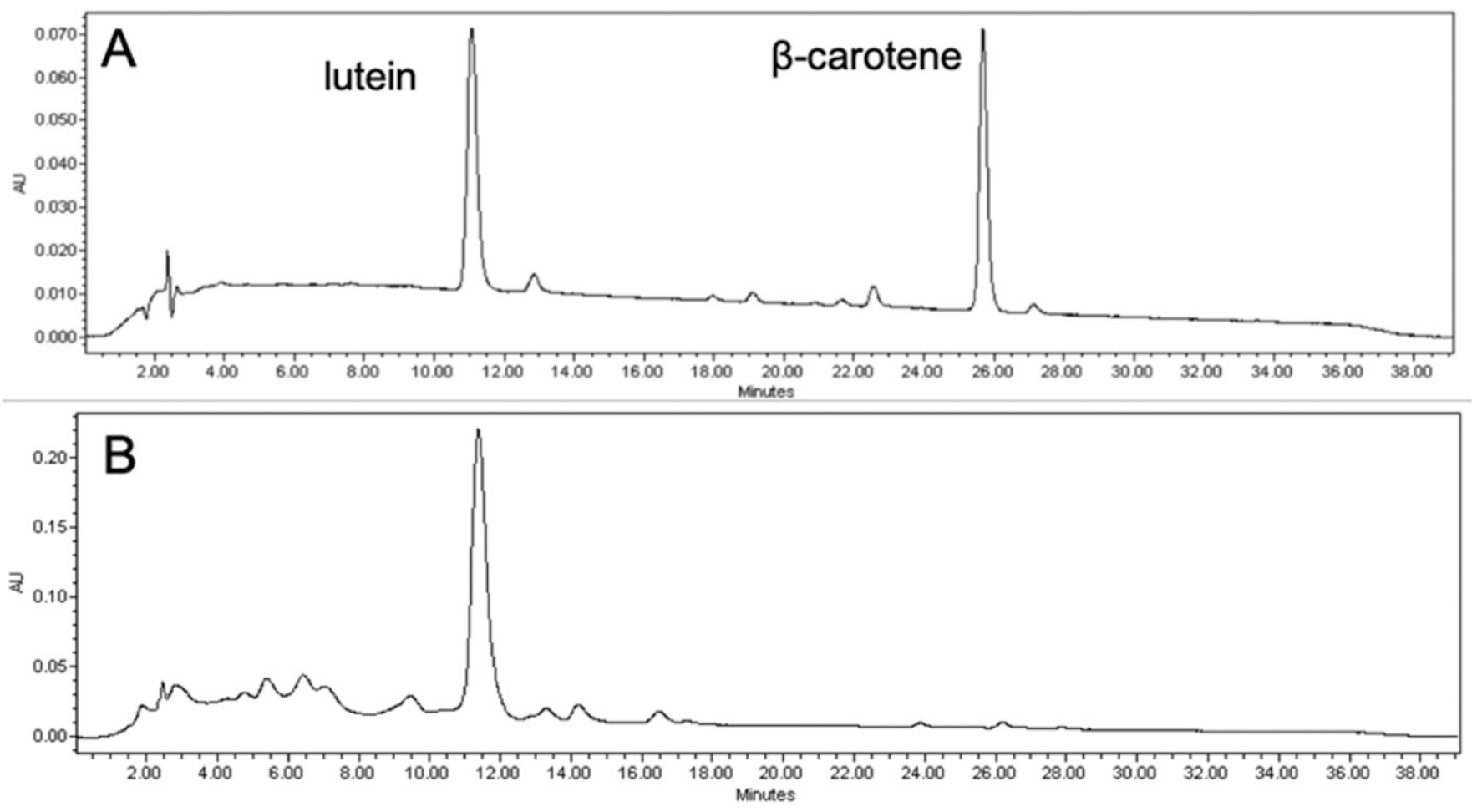

Fig. 3. High-performance liquid chromatography chromatograms of (A) lutein and $\beta$-carotene standards and (B) 'NuMex LotaLutein' carotenoid extract.

Table 2. Lutein and total carotenoid contents for 'NuMex LotaLutein' and previously published pepper carotenoids.

\begin{tabular}{lccl}
\hline Cultivar & Lutein $\left(\mu \mathrm{g} \cdot \mathrm{g}^{-1} \mathrm{DW}\right)$ & Total carotenoids $\left(\mu \mathrm{g} \cdot \mathrm{g}^{-1} \mathrm{DW}\right)$ & Reference \\
\hline NuMex LotaLutein & $21.9 \pm 1.5^{\mathrm{z}}$ & $32.7 \pm 4.7^{\mathrm{z}}$ & Collera-Zuñiga et al. (2005) \\
Ancho & 0 & 75.20 & Collera-Zuñiga et al. (2005) \\
Guajillo & 0 & 67.60 & Collera-Zuñiga et al. (2005) \\
Mulato & 0.64 & 72.40 & Hervert-Hernandez et al. (2010) \\
Arbol & 0 & 3658.0 & Hervert-Hernandez et al. (2010) \\
Chipotle & 0 & 1914.0 & Hervert-Hernandez et al. (2010) \\
Guajillo & 7.71 & 876.0 & Hervert-Hernandez et al. (2010) \\
Morita & 70.18 & 3733.0 & Kim et al. (2010) \\
Red Paprika & 24.2 & 694.4 & Minguez-Mosquera and Hornero-Mendez (1993) \\
Agridulce & nd & $1359.98 \mathrm{mg} \cdot \mathrm{kg}^{-1} \mathrm{FW}$ & Minguez-Mosquera and Hornero-Mendez (1993) \\
Bola & nd & $961.8 \mathrm{mg} \cdot \mathrm{kg}^{-1} \mathrm{FW}$ &
\end{tabular}

${ }^{\mathrm{z}}$ Means $\pm \mathrm{SD}$ of three replicates with five plants per replication in 2 years.

$\mathrm{DW}=$ dry weight; $\mathrm{FW}=$ fresh weight; nd = not detectable.

in the total amounts of carotenoids from one year to the next across cultivars, depending on changes in environment; however, the percent of lutein relative to other carotenoids will remain the same in this cultivar.

'NuMex LotaLutein' will be a valuable addition to growers needing a competitive edge in the marketplace and gardeners desiring a serrano with a new fruit color that is high in lutein. In addition, the food processing industry can use 'NuMex LotaLutein' to add health benefits to their products on the shelf.

\section{Availability}

'NuMex LotaLutein' seed is available from the Chile Pepper Institute, New Mexico State University, P.O. Box 30003, MSC 3Q,
Las Cruces, NM 88003. The Chile Pepper Institute can be contacted at www.cpi.org or by phone (575) 646-3028.

\section{Literature Cited}

Bosland, P.W. 1993. An effective plant field-cage to increase the production of genetically pure chile (Capsicum spp.) seed. HortScience 28: 1053, doi: 10.21273/HORTSCI.28.10.1053.

Bosland, P.W. and E. Votava. 2012. Peppers: Vegetable and spice Capsicums. 2nd ed. CAB International, Wallingford, UK.

Bosland, P.W. and S. Walker. 2014. Growing chiles in New Mexico. New Mexico State Univ. Coop. Ext. Serv. H-230.

Buscemi, S., D. Corleo, F. Di Pace, M.L. Petroni, A. Satriano, and G. Marchesini. 2018. The effect of lutein on eye and extra-eye health. Nutrients 10:1321, doi: 10.3390/nu10091321.

Collera-Zuñiga, O., F. Garcia Jimenez, and R. Melendez Gordillo. 2005. Comparative study of carotenoid composition in three Mexican varieties of Capsicum annuum L. Food Chem. 90:109-114, doi: 10.1016/j.foodchem.2004.03.032.

Collins, M.D., L. Mayer-Wasmund, and P.W. Bosland. 1995. Improved method for quantifying capsaicinoids in Capsicum using high-performance liquid chromatography. HortScience 30:137-139, doi: 10.21273/HORTSCI.30.1.137.

Guzman, I., S. Hamby, J. Romero, P.W. Bosland, and M.A. O'Connell. 2010. Variability of carotenoid biosynthesis in orange colored Capsicum spp. Plant Sci. 179:49-59, doi: 10.1016/ j.plantsci.2010.04.014.

Hervert-Hernandez, D., S.G. Sayago-Ayerdi, and I. Goñi. 2010. Bioactive compounds of four hot pepper varieties (Capsicum annuum L.), antioxidant capacity, and intestinal bioaccessibility. J. Agr. Food Chem. 58:3399-3406, doi: $10.1021 / \mathrm{jf} 904220 \mathrm{w}$.

Johnson, E. 2002. The role of carotenoids in human health. Nutr. Clin. Care 5:56-65, doi: 10.1046/ j.1523-5408.2002.00004.x.

Kim, J.S., J. Ahn, S.J. Lee, B.K. Moon, T.Y. Ha, and S. Kim. 2010. Phytochemicals and 
antioxidant activity for fruits and leaves of paprika (Capsicum annuum L., var. Special) cultivated in Korea. J. Food Sci. 76:C193C198, doi: 10.1111/j.1750-3841.2010.01891.x. Minguez-Mosquera, M. and D. Hornero-Mendez. 1993. Separation and quantitation of the carotenoid pigments in red peppers (Capsicum annuиm
L.), paprika, and oleoresin by reversed-phase HPLC. J. Agr. Food Chem. 41:1616-1620, doi: 10.1021/jf00034a018.

Munsell Book of Color. 1980. Glossy edition. Xrite Incorporated, Grand Rapids, MI.

Richins, R.D., J. Kilcrease, L. Rodriguez-Uribe, and M.A. O'Connell. 2014. Carotenoid ex- traction and quantification from Capsicum annuum. Bio Protoc. 4:1-10, doi: 10.21769/ BioProtoc. 1256.

Steiner, B.M., D.J. McClements, and G. DavidovPardo. 2018. Encapsulation systems for lutein: A review. Trends Food Sci. Technol. 82:71-81, doi: 10.1016/j.tifs.2018.10.003. 